showed almost complete absence of bacteria in the air of the operating tent. The significance of contamination of operation wounds by contamination of the room air and the importance of its prevention seem proved.

Zusammenfassung. Im ultrareinen Operationsraum mit lamellarer Luftströmung betrug bei 192 aseptischen Operationen die Infektionsrate ca. 1/2\%. Bakteriologische Untersuchungen ergaben weitgehende Keimfreiheit der Luft im Operationszelt. Die Bedeutung der Kontamination von Operationswunden durch Verunreinigungen der Raumluft und die Wichtigkeit ihrer Verhütung scheint damit erwiesen zu sein.

\title{
318. Früherkennung der akuten posttraumatischen Osteomyelitis durch bakteriologische Untersuchung der Redon-Drainagen
}

\section{B. Friedrich *, V. Fischer, W. Ferbert und W. DölL-Würzburg}

\section{Early Recognition of Post-Traumatic Osteomyelitis through Bacteriological Examination of the Redon-Drainage}

Summary. The tips of the inserted Redon-drainage-tubes were bacteriologically examined after 50 operations on the extremities which included 37 osteosyntheses. The withdrawal was carried out about $48 \mathrm{~h}$ after the operation. The tips of the drainage tubes were sterile in 28 cases, only once did we find a slight infection of the operational wound. In six cases we observed an acute post-traumatic osteomyelitis and in another five infections of the soft tissues without bone participation. In all 11 cases germs were present in the tip of the Redon-drain. In the osteomyelitis cases and in three with severe soft tissue infections the infective organisms always were staphylococci.

Therefore, it seems possible to obtain a detailed account of the possible bacterial invasions of the operation wound already on the 3rd to the 4th day after the operation. The basis for a selective and rapid onset of therapy is thus warranted.

Zusammenfassung. Bei 50 Eingriffen an Extremitäten, darunter 37 Osteosynthesen, wurden die Spitzen der eingebrachten Redon-Drainagen bakteriologisch untersucht. Die Entnahme erfolgte ca. $48 \mathrm{Std}$ nach der Operation. $28 \mathrm{mal}$ waren die Drain-Spitzen steril, nur 1 mal fanden wir darunter einen leichten Infekt der Operationswunde. 6 mal sahen wir eine akute posttraumatische Osteomyelitis, weitere $5 \mathrm{mal}$ Weichteilinfekte ohne Beteiligung des Knochens. Bei allen diesen 11 Fällen konnten an der Spitze des Redon-Drains Keime nachgewiesen werden, bei den Osteomyelitiden sowie 3 schweren Weichteilinfekten jedesmal Staphylokokken.

Es scheint somit möglich, bereits am 3.-4. postoperativen Tage eine differenzierte Auskunft über eine eventuelle Keimbesiedelung der Operationswunde erhalten zu können. Damit ist die Basis für einen gezielten und schnellen Therapieeinsatz gewährleistet. 